\title{
ANALISIS MUTU BATU BATA MERAH PEJAL TRADISIONAL DI JAKARTA TERHADAP SNI 15-2094-2000
}

\author{
Tommy Syaelendra, Erna Septiandini, Nira Nasution
}

\begin{abstract}
Abstrak
Penelitian ini bertujuan untuk mengetahui kualitas bata merah pejal tradisional yang di distribusikan di Jakarta dengan menggunakan SNI 15-2094-2000 sebagai acuannya. Pengujiannya berupa pengujian sifat tampak, ukuran dan toleransi, kuat tekan, penyerapan air, kerapatan semu dan kandungan garam yang berbahaya.

Penelitian ini menggunakan metode eksperimen dan deskriptif. Sampel yang digunakan sebanyak 30 buah benda uji dari toko material. Di setiap kotamadya diambil 3 toko material untuk diambil 30 buah benda uji. Di Jakarta terdapat 5 Wilayah, maka dari 5 Wilayah tersebut didapat 450 buah benda uji. Data yang diperoleh dari hasil penelitian di laboratorium yaitu bata merah pejal yang diuji dilihat dari ukuran dan toleransi serta dilihat dari kuat tekannya tidak memenuhi standar.

Kesimpulan dari penelitian ini adalah 1). Hasil analisis dari ketiga pengujian sifat tampak tersebut menunjukkan sampel batu bata merah pejal tradisional di tiap-tiap wilayah memenuhi SNI 15-2094-2000. 2). Hasil analisis ukuran dan toleransi batu bata merah pejal tradisional di tiap-tiap wilayah tidak memenuhi SNI 15-2094-2000. 3). Hasil analisa untuk kuat tekan rata-rata wilayah TX, TZ, SX, SZ, BX dan UY tidak memenuhi tingkat mutu bata merah pejal yang ada di SNI 15-20942000 karena hasil kuat tekan rata-rata $<50 \mathrm{~kg} / \mathrm{cm}^{2}$. Sedangkan nilai kuat tekan wilayah TY, SY, BY, BZ, UX,UZ, PX, PY dan PZ memenuhi tingkat mutu bata merah pejal yang ada di SNI 15-2094-2000 karena hasil kuat tekan rata-rata $>50 \mathrm{~kg} / \mathrm{cm}^{2}$. 4). hasil analisa penyerapan air untuk wilayah TX-TY, SX-SY-SZ, BX-BY-BZ, UX-UY-UZ dan PX-PY$P Z$ lulus uji SNI 15-2094-2000. 5). Hasil analisa untuk kerapatan semu adalah semua wilayah dari bata merah pejal memenuhi mutu SNI 152094-2000. 6). Hasil analisa kandungan garam yang berbahaya di tiaptiap wilayah memenuhi SII 0021 - 78, karena nilai kandungan garam kurang dari $50 \%$.
\end{abstract}

Kata kunci : bata merah pejal, kuat tekan

Tommy Syaelendra

Alumni Jurusan Teknik Sipil

Fakultas Teknik

Universitas Negeri Jakarta, 13220
Ir. Erna Septiandini, MT Staff Pengajar Jurusan Teknik Sipil Fakultas Teknik Universitas Negeri Jakarta, 13220
Dra. Nira Nasution, M.Pd Staff Pengajar Jurusan Teknik Sipil Fakultas Teknik Universitas Negeri Jakarta, 13220 


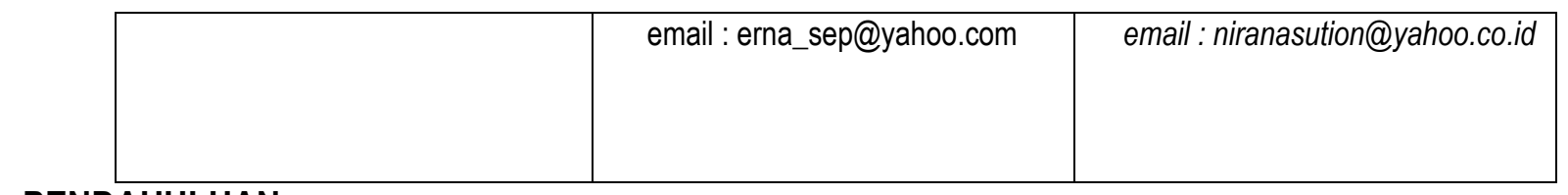

\section{PENDAHULUAN}

Pembangunan perumahan di Jakarta sebagai salah satu kebutuhan pokok semakin meningkat sesuai dengan pertambahan jumlah penduduk. Saat ini banyak sekali berdiri bangunan seperti perumahan, apartemen rumah susun dan sebagainya. Sebagian besar masyarakat saat ini masih menggunakan bata merah pejal tradisional sebagai bahan bangunan yang digunakan untuk komponen dinding, sehingga kebutuhan bata merah pejal tradisional pada saat ini masih tergolong cukup tinggi.

Bata merah pejal tradisional sebagai salah satu bentuk dari bahan bangunan, tidak lepas dari pengamatan bidang teknik bangunan. Dari segi teknis, bata merah pejal tradisional diharuskan memiliki spesifikasi tertentu, yaitu untuk dinding pemisah ruangan. Dengan meningkatnya pembangunan di Jakarta, baik dalam bidang perumahan, gedung bertingkat, maupun sarana dan prasarana. Dan juga banyak diminati karena harganya yang dapat terjangkau oleh masyarakat. Maka permintaan pasokan bata merah pejal tradisional di Jakarta pun akan banyak pula.

Dengan semakin dibutuhkan oleh masyarakat, maka segi kualitas atau mutu pun harus dijaga agar dapat memenuhi standar. Mutu dan kualitas bata merah pejal tradisional merupakan salah satu faktor terpenting, karena keselamatan pemakai bata merah pejal tradisional akan lebih terjamin.

Sering kita jumpai di lapangan pada umumya mutu bata merah pejal tradisional dengan tampilan kurang baik, seperti mudah rapuh, retak-retak pada permukaan, ukuran yang tidak seragam, warna pada penampang bata tidak merata, tidak siku. Hal ini akan mempengaruhi kualitas dari bangunan dinding yang digunakan.

Proses produksi bata merah pejal tradisional di Indonesia saat ini masih didominasi oleh industri kecil (home industry). Dimana proses pembuatannya umumnya masih secara tradisional, hal ini dapat kita lihat dari sistem pembakaran batu bata merah pejal tradisional yang masih menggunakan tungku. Penggunaan tungku dalam proses pembakaran menggunakan bahan bakar kayu sehingga hasil pembakaran yang diperoleh pun akan bervariasi. Hasil yang bervariasi ini dapat mempengaruhi kualitas batu bata merah pejal tradisional yang di produksi. Selain itu proses pencampuran bahan yang kurang homogen, ketidakteraturan dan ketidakstabilan komposisi dari proses pembuatan bata merah pejal tradisional itu sendiri kurang diperhatikan, 
sehingga akan berakibat mudah rapuh, dan kurang sempurnanya proses pembakaran bata tersebut.

Selain itu pemilihan bahan dasar di dalam pembuatan bata merah pejal tradisional juga perlu diperhatikan. Karena juga akan berpengaruh pada mutu serta keawetan bata merah pejal tradisional yang dihasilkan. Oleh karena itu pemilihan bahan dasar yang tepat diharapkan mengurangi kemungkinan timbulnya pengaruh yang merugikan, serta diharapkan dapat meningkatkan kekuatan dan keawetan batu bata merah pejal tradisional.

Mutu bata merah pejal terdiri dari beberapa komponen mutu. Seringkali belum diketahui oleh masyarakat, sehingga didalam memilih bata merah pejal dipasaran hanya berdasarkan pada kebiasaan maupun kecenderungan memilih produk dari produsen tertentu yang telah banyak dipilih orang lain tanpa mengetahui kualitas yang sebenarnya sehingga sering terjadi kesalahan didalam memilih bata merah pejal.

Dengan adanya SNI 15-2094-2000 tentang syarat mutu dan cara uji bata merah pejal tradisional sebagai acuan yang digunakan, maka menjadi hal yang menarik untuk dianalisis mutu bata merah pejal tradisional yang di distribusikan di Jakarta. Dimana peneliti akan menguji mutu bata merah pejal tradisional. pengujian bata merah pejal tradisional meliputi sifat tampak, ukuran dan toleransi, kuat tekan, garam yang membahayakan, kerapatan semu dan penyerapan air.

Menurut Drs. IK Supribadi dalam buku IImu Bangunan Gedung, bata merah pejal tradisional adalah batu buatan yang berasal dari tanah liat yang dalam keadaan lekat dicetak, dijemur beberapa hari sesuai dengan aturan lalu dibakar sampai matang, sehingga tidak dapat hancur lagi bila direndam air. Bata merah pejal merupakan bahan bangunan yang paling umum di gunakan, bata juga lazim disebut orang dengan batu bata. Sedangkan menurut SNI 15-20942000 , bata merah pejal tradisional adalah bahan bangunan yang berbentuk prisma segi empat panjang, pejal atau berlubang dengan volume lubang maksimum $15 \%$, dan digunakan untuk konstruksi dinding bangunan, yang dibuat dari tanah liat dengan atau tanpa dicampur bahan aditif dan dibakar pada suhu tertentu. Penggunaan bata merah pejal yang dibakar untuk bahan bangunan telah dimulai dari zaman prasejarah oleh karena tingkat keawetan dari batu bata yang telah dibakar dengan baik dan cukup kuat melalui exposure dalam berbagai keadaan iklim. Unit bata yang modern telah dibuat dalam berbagai macam ukuran, bentuk, warna dan tekstur guna memenuhi ketentuan dari arsitektur modern.

Menurut Drs. Daryanto dalam buku pengetahuan teknik bangunan Bata merah pejal saat ini sedang dikembangkan macam-macam tipe campuran, antara lain : (1) campuran bahan tanah 
liat + tanah kapur + kapur bubuk + semen, (2)campuran bahan tras kapur, dan (3) campuran bahan tanah liat + pasir + kapur bubuk + PC.

Bentuk bata merah pejal umumnya merupakan prisma tegak (balok) dengan penampang empat persegi panjang. Ukuran bata merah pejal di berbagai tempat dan daerah tidak sama besarnya disebabkan oleh karena belum adanya keseragaman ukuran dan teknik pengolahan. Biasanya bata merah pejal yang ada dipasaran berkisar antara $22 \times 10 \frac{1}{2} \times 4.8 \mathrm{~cm}$ sampai $24 \times 11 \frac{1}{2} \mathrm{x}$ $5 \frac{1}{2} \mathrm{~cm}$.

Jumlah benda-benda percobaan yang boleh menunjukan penyimpangan dalam ukuran-ukuran lebih dari penyimpangan maksimum yang telah ditentukan oleh :

Tabel 1. Ukuran-Ukuran Penyimpangan Bata Merah Pejal

\begin{tabular}{|c|c|}
\hline Kelas Bata Merah Pejal & Penyimpangan Ukuran \\
\hline Mutu Tingkat I & Tidak ada penyimpangan \\
\hline Mutu Tingkat II & Satu buah dari sepulih benda percobaan \\
\hline mutu tingkat III & Dua dari sepuluh benda percobaan \\
\hline
\end{tabular}

Sumber : Drs. Daryanto, Pengetahuan Teknik Bangunan (Jakarta : Bina Aksara1988)

Menurut V.N Varianzi dan S. P. Chandola dalam buku Consise Handbook of Civil Engineering (1996) Kekuatan bata merah pejal tergantung pada faktor- faktor :

(1) Komposisi material penyusun lempung,

(2) Pengolahan lempung dan pencetakannya,

(3) Pengeringan,

(4) Proses pembakaran dan pengeringan.

Menurut Standar Nasional Indonesia No. 15 - 2094 - 2000 ada enam syarat mutu bata merah pejal, yaitu :

1 Sifat Tampak

Bata merah pejal untuk pasangan dinding harus berbentuk prisma segi empat panjang, mempunyai rusuk-rusuk yang siku, bidang-bidang datar yang rata dan tidak menunjukan retakretak.

2 Ukuran dan Toleransi

Tabel 2. Ukuran dan toleransi bata merah pejal untuk pasangan dinding. 


\begin{tabular}{|c|c|c|c|}
\hline Modul & Tinggi & Lebar & Panjang \\
\hline M- 5a & $65 \pm 2$ & $90 \pm 3$ & $190 \pm 4$ \\
M- $5 b$ & $65 \pm 2$ & $100 \pm 3$ & $190 \pm 4$ \\
M-6a & $52 \pm 3$ & $110 \pm 4$ & $230 \pm 5$ \\
M-6b & $55 \pm 3$ & $110 \pm 6$ & $230 \pm 5$ \\
M-6c & $70 \pm 3$ & $110 \pm 6$ & $230 \pm 5$ \\
M- $6 d$ & $80 \pm 3$ & $110 \pm 6$ & $230 \pm 5$ \\
\hline
\end{tabular}

Sumber : SNI 15-2094-2000

3. Kuat Tekan

Tabel 3. Kuat tekan dan koe

fisien untuk bata merah pejal pasangan dinding

\begin{tabular}{|c|c|c|}
\hline Kelas & $\begin{array}{c}\text { Kuat tekan rata-rata minimum } \\
\text { dari } 30 \text { bata yang diuji } \mathbf{~ k g} / \mathbf{c m}^{2} \\
\text { (MPa) }\end{array}$ & $\begin{array}{c}\text { Koefisien variasi dari kuat } \\
\text { tekan rata-rata yang diuji } \\
\text { (\%) }\end{array}$ \\
\hline 50 & $50(5)$ & 22 \\
100 & $100(10)$ & 15 \\
150 & $150(15)$ & 15 \\
\hline
\end{tabular}

Sumber : SNI 15-2094-2000

4. Garam yang Membahayakan

Berdasarkan SII 0021-78, garam yang mudah larut dan membahayakan serta yang dapat menyebabkan terjadinya kerusakan struktural Efflorescence pada permukaan bata adalah magnesium sulfat $\left(\mathrm{MgSO}_{4}\right)$, natrium sulfat $\left(\mathrm{Na}_{2} \mathrm{SO}_{4}\right)$, kalium sulfat $\left(\mathrm{K}_{2} \mathrm{SO}_{4}\right)$, dengan total kadar garam kurang dari $50 \%$.

5. Kerapatan Semu minimum bata merah pejal untuk pasangan dinding adalah $1,2 \mathrm{gram} / \mathrm{cm}^{2}$

6 Penyerapan Air maksimum bata merah pejal untuk pasangan dinding adalah $20 \%$.

Dalam penelitian Muhammad Nur Rokib tentang "Pengaruh Posisi Pembakaran Dalam Tungku Terhadap Daya Lekat (Bond Shear) Bata Merah Pejal" Tahun 2002 yang dilakukan dengan sampel sebanyak 15 buah dari tiap-tiap posisi pembakaran. Hasil penelitian ini adalah bata merah pejal yang berada di susunan tengan mempunyai daya lekat (bond shear) yang optimum karena tempratur yang ideal tidak terlalu panas dan tidak kurang suhunya.

Dalam Penelitian Lili Chandra tenang "Studi Kuat Tekan Bata Merah Pejal Beralur Untuk Pasangan Dinding" tahun 2003 yang dilakukan dengan sampel sebanyak 20 buah. Hasil penelitian ini adalah (1). Tidak terdapat perbedaan kuat tekan pada bata merah pejal beralur 4,7 dan 9. Hal ini dikarenakan pada proses pembuatan benda uji alur-alur yang terdapat pada bata 
merah pejal terisi oleh spesi (mortar) jadi banyaknya alur pada bata merah pejal beralur tidak mempengaruhi kuat tekan. (2). Kuat tekan bata merah pejal beralur optimum memenuhi dari persyaratan kuat tekan bata merah pejal standar (SNI). Hal ini dikarenakan pada proses pembuatan bata merah pejal beralur dilakukan dengan cara pengerjaan yang baik, baik dari peoses memilih bahan dasar dan proses pencetakan.

Dalam Penelitian Kardi tentang "Studi Modulus Elastisitas Bata Merah Pejal Terhadap Posisi Pembakaran Dalam Tungku" yang dilakukan dengan sampel sembanyak 22 buah dari tiap lapisan. Hasil penelitian tersebut yaitu (1). Nilai modulus elastiitas rata-rata bata merah pejal yang dilapisi spesi pada posisi atas lebih kecil dari posisi tengah dan posisi tengah lebih kecil dari posisi bawah pembakaran dalam tungku yaitu : 11,599GPa < 19,231GPa < 23,341 Gpa. (2) Besarnya perbedaan nilai modulus elastisitas bata merah pejal yang telah dilapisi spesi terhadap posisi pembakaran dalam tungku dilapisan atas tengah dan bawah adalah $1: 1,7: 2,0$.

Dalam penelitian Dian Wulandari tentang "Studi Pengujian Tegangan Geser Bata Merah Pejal" tahun 2004 yang dilakukan dengan sampel sebanyak 20 buah didapat nilai terendah sebesar $0.217 \mathrm{MPa}$ dan nilai tertinggi sebesar $1.505 \mathrm{MPa}$. Jadi nilai rata-rata tegangan geser bata merah pejal adalah 0.8288 .

Bata atau bata merah adalah batu buatan yang berasal dari tanah liat yang dalam keadaan lekat dicetak, dijemur beberapa hari sesuai dengan aturan lalu dibakar sampai matang, sehingga tidak dapat hancur lagi bila direndam air. tanah liat yang digunakan diambil dari lahan persawahan yang terletak disekitar lokasi pembuatan. Bata merupakan bahan bangunan yang paling umum di gunakan, bata juga lazim disebut orang dengan batu bata.

Selama berlangsung dan setelah proses pembuatan bata merah pejal tradisional selesai, tidak dilakukan "quality control", hal ini disebabkan tidak adanya peralatan yang memadai serta ketidaktahuan tentang syarat mutu bata merah pejal karena kebanyakan didominasi oleh industri kecil (home industry). Bata merah pejal sebelum dipasarkan seharusnya dilakukan pengecekan mutu bata merah yang mengacu pada SNI 15 - 2094 - 2000, pengecekan mutu lebih tekankan pada penyerapan air dan sifat tampak bata yang meliputi panjang bata, rusuk-rusuk yang siku, bidang datar yang rata, tidak menunjukkan retak-retak dan bila diketuk suaranya nyaring.

Kebanyakan masyarakat Jakarta belum banyak mengetahui tentang syarat mutu bata merah pejal seperti yang disyaratkan dalam SNI 15-2094-2000 dalam hal ini masyarakat lebih mengetahui tentang sifat tampaknya saja.

\section{METODA}


Tujuan penelitian ini adalah untuk mengetahui Apakah mutu bata merah pejal tradisional di Jakarta memenuhi keenam syarat mutu SNI 15-2094-2000. yaitu :

1) Sifat tampak

2) Ukuran dan toleransi

3) Kuat tekan

4) Garam yang berbahaya

5) Kerapatan semu

6) Penyerapan air

Berdasarkan tujuan penelitian diatas, maka metode penelitian ini adalah metode eksperimen dan metode deskriptif

Penelitian ini melibatkan dua variabel, yaitu :

1) Variabel $X$ ( Variabel Bebas ) : Batu bata merah pejal

2) Variabel $Y$ ( Variabel Terikat ) : : Sifat Tampak

2. Ukuran dan Toleransi

3. Kuat Tekan

4. Garam yang Membahayakan

5. Kerapatan Semu

6. Penyerapan Air

Populasi menurut Sudjana adalah totalitas semua nilai yang mungkin, baik hasil menghitung maupun pengukuran, kualitatif maupun kuantitatif, daripada karakteristik tertentu mengenai sekumpulan objek yang lengkap dan jelas. Populasi sasaran dalam penelitian ini adalah bata merah pejal. Sampel dari penelitian ini diambil secara acak ( sample random ), diambil sebanyak 30 buah benda uji dari toko material. Di setiap kotamadya diambil 3.toko material untuk diambil 30 buah benda uji. Di Jakarta terdapat 5 Wilayah, maka dari 5 Wilayah tersebut didapat 450 buah benda uji.

Tabel 4. Hasil Survey Bata Merah Pejal Tradisional di Jakarta.

\begin{tabular}{|c|c|c|c|c|}
\hline Wilayah & Toko Material & Alamat & Sumber Bahan & $\begin{array}{c}\text { Jumlah } \\
\text { Bahan }\end{array}$ \\
\hline \multirow{3}{*}{$\begin{array}{l}\text { Jakarta } \\
\text { Timur }\end{array}$} & TB. Jaya (TX) & $\begin{array}{l}\text { Jl. I Gusti Ngurah Rai Klender } \\
\text { Jakarta Timur }\end{array}$ & Wadas Karawang & 30 Buah \\
\hline & TB. Anugerah (TY) & $\begin{array}{l}\text { Jl. Batu ampar } 3 \text { Condet } \\
\text { Jakarta Timur }\end{array}$ & $\begin{array}{l}\text { Parung Panjang } \\
\text { Bogor }\end{array}$ & 30 Buah \\
\hline & TB. Gunung Agung (TZ) & $\begin{array}{l}\text { Jl. H. Kaping Kp. Rambutan } \\
\text { Jakarta Timur }\end{array}$ & Cibitung Bekasi & 30 Buah \\
\hline
\end{tabular}




\begin{tabular}{|c|c|c|c|c|}
\hline Wilayah & Toko Material & Alamat & Sumber Bahan & $\begin{array}{l}\text { Jumlah } \\
\text { Bahan }\end{array}$ \\
\hline \multirow{3}{*}{$\begin{array}{l}\text { Jakarta } \\
\text { Selatan }\end{array}$} & TB. Bangunan Jaya (SX) & $\begin{array}{l}\text { Jl. Jati Utara Pondok Labu } \\
\text { Jakarta Selatan }\end{array}$ & $\begin{array}{c}\text { Hegarmegah Lemah } \\
\text { Bbang }\end{array}$ & 30 Buah \\
\hline & TB. Мајu (SY) & $\begin{array}{l}\text { Permata Hijau } 2 \text { Kebayoran } \\
\text { lama Jakarta Selatan }\end{array}$ & $\begin{array}{l}\text { Mulya Jaya } \\
\text { Lemah Abang }\end{array}$ & 30 Buah \\
\hline & TB. Sumber Alam (SZ) & $\begin{array}{l}\text { Jl. Kali Bata Utara Jakarta } \\
\text { Selatan }\end{array}$ & & 30 Buah \\
\hline \multirow{3}{*}{$\begin{array}{c}\text { Jakarta } \\
\text { Barat }\end{array}$} & TB. Ahmad (BX) & $\begin{array}{l}\text { Jl. Meruya llir } \\
\text { Jakarta Barat }\end{array}$ & Serpong Tangerang & 30 Buah \\
\hline & TB. Anugerah (BY) & $\begin{array}{l}\text { JI. Semanan Raya Daan mogot } \\
\text { Jakarta Barat }\end{array}$ & Kulim Pekanbaru & 30 Buah \\
\hline & TB. Hj Ismed (BZ) & $\begin{array}{l}\text { Kemanggisan Kebon Jeruk } \\
\text { Jakarta Barat }\end{array}$ & $\begin{array}{l}\text { Batu Ceper } \\
\text { Tangerang }\end{array}$ & 30 Buah \\
\hline \multirow{3}{*}{$\begin{array}{l}\text { Jakarta } \\
\text { Utara }\end{array}$} & TB. Terang (UX) & $\begin{array}{l}\text { JI. Kelapa Cingkir Kelapa } \\
\text { Gading Jakarta Utara }\end{array}$ & & 30 Buah \\
\hline & TB. Kudus (UY) & $\begin{array}{l}\text { Jl. Sunter Agung Sunter } \\
\text { Jakarta Utara }\end{array}$ & $\begin{array}{c}\text { Cipendeuy } \\
\text { Bandung Barat }\end{array}$ & 30 Buah \\
\hline & TB. Bangunan Jaya (UZ) & $\begin{array}{l}\text { Jl. Mawar, Rawa Badak Koja } \\
\text { Jakarta Utara }\end{array}$ & Lemah Abang & 30 Buah \\
\hline \multirow{3}{*}{$\begin{array}{l}\text { Jakarta } \\
\text { Pusat }\end{array}$} & TB. Cahaya (PX) & $\begin{array}{l}\text { Jl. Percetakan Negara Jakarta } \\
\text { Pusat }\end{array}$ & & 30 Buah \\
\hline & TB. Syukur (PY) & $\begin{array}{l}\text { Jl. Cikini Raya } \\
\text { Jakarta Pusat }\end{array}$ & $\begin{array}{c}\text { Barengkok Leuliang } \\
\text { Bogor }\end{array}$ & 30 Buah \\
\hline & TB. Hikmah (PZ) & $\begin{array}{l}\text { Jl. Minangkabau Manggarai } \\
\text { Jakarta Pusat }\end{array}$ & $\begin{array}{l}\text { Gunung Tangkil } \\
\text { Bogor }\end{array}$ & 30 Buah \\
\hline \multicolumn{3}{|c|}{ Jumlah Keseluruhan } & & 450 Buah \\
\hline
\end{tabular}

Tabel 5. Kebutuhan Batu Bata Merah Pejal untuk masing-masing penelitian.

\begin{tabular}{|l|c|}
\hline \multicolumn{1}{|c|}{ NAMA PENGUJIAN } & JUMLAH BATA MERAH PEJAL TRADISIONAL \\
\hline Kerapatan Semu & YANG DI BUTUHKAN \\
\hline Ukuran dan Toleransi & 10 Buah Bata Merah Pejal Tradisional \\
\hline Kuat Tekan & \\
\hline Penyerapan Air & 10 Buah Bata Merah Pejal Tradisional \\
\hline Sifat Tampak & 10 Buah Bata Merah Pejal Tradisional \\
\hline Garam Yang Berbahaya
\end{tabular}

Data hasil survey di lokasi sampel, wawancara dan hasil pengujian di laboratorium tersebut kemudian digunakan sebagai data primer. Teknik pengumpulan data pada penelitian ini dilaksanakan dengan melakukan pengujian mutu Bata merah pejal tradisonal yang meliputi sifat tampak, ukuran dan toleransi, kuat tekan, penyerapan air, kerapatan semu dan garam yang berbahaya. Terlebih dahulu peneliti melakukan survey ke toko-toko material yang ada di Jakarta.

\section{HASIL DAN PEMBAHASAN}

\section{Sifat Tampak}

Sesuai dengan SNI 15-2094-2000 pengujian bata merah pejal pada sifat tampak harus memenuhi persyaratan antara lain bidang permukaan bata merah pejal harus rata, rusuk- 
rusuknya siku satu terhadap yang lain, tidak menunjukan retak-retak di permukaan. Hasil penelitian untuk pengujian sifat tampak pada sampel dari tiap-tiap kelompok memenuhi SNI 152094-2000. Sehingga berdasarkan SNI 15-1328-1989 dengan nilai tingkat mutu lulus uji sebesar $5.0 \%$ seluruh sampel di tiap-tiap kelompok diterima.

Sedangkan pada hasil penelitian Temmy Ardian Darwin dengan judul "Pengaruh Bahan Tambah Serat Serabut Kelapa Terhadap Mutu Bata Merah Pejal Dengan SNI 15-2094-2000". Diperoleh hasil sifat tampak dari 10 sampel masing-masing mempunyai rusuk yang siku permukaan yang rata dan tidak menunjukan retak-retak pada permukaan bata merah pejal.

\section{Ukuran dan Toleransi}

Sesuai dengan Tabel ukuran dan toleransi dalam SNI 15-2094-2000, maka pengujian ukuran dan toleransi yaitu pengujian dimensi (panjang, lebar, tinggi). Pada pengujian ukuran dan toleransi bata merah pejal, toleransi yang diijinkan adalah panjang minimum $19.0 \mathrm{~cm}$ dan maksimum 19,4, lebar minimum $9.0 \mathrm{~cm}$ dan maksimum $9.2 \mathrm{~cm}$, tinggi minimum $6,5 \mathrm{~cm}$ dan maksimum $6,7 \mathrm{~cm}$.

Dari hasil penelitian untuk pengujian ukuran dan toleransi pada seluruh sampel dari tiaptiap kelompok tidak memenuhi SNI 15-2094-2000. Sehingga berdasarkan SNI 15-1328-1989 dengan nilai tingkat mutu lulus uji sebesar $5.0 \%$ seluruh sampel di tiap-tiap kelompok ditolak.

Sedangkan pada hasil penelitian Temmy Ardian Darwin dengan judul "Pengaruh Bahan Tambah Serat Serabut Kelapa Terhadap Mutu Bata Merah Pejal Dengan SNI 15-2094-2000". Diperoleh hasil ukuran dan toleransi dari 10 sampel masing-masing mempunyai Panjang 19.20, Lebar 9,17 dan tebal 4.55 .

\section{Kuat Tekan}

Pengujian kuat tekan kelompok TX dari 10 buah sampel pengujian 2 buah sampel yang memenuhi SNI 15-2094-2000 dan 8 buah sampel tidak memenuhi SNI 15-2094 -2000. Sehingga berdasarkan SNI 15-1328-1989 dengan nilai tingkat mutu lulus uji sebesar 5.0 \% kelompok TX ditolak. Sedangkan nilai rata-rata kuat tekan kelompok TX adalah $45.10 \mathrm{Kg} / \mathrm{cm}^{2}$. Maka kelompok TX tidak memenuhi persyaratan SNI yaitu $<50 \mathrm{~kg} / \mathrm{cm}^{2}$.

Untuk pengujian kuat tekan kelompok TY dari 10 buah sampel pengujian 8 buah sample yang memenuhi SNI 15-2094-2000 dan 2 buah sampel yang tidak memenuhi SNI 15-2094-2000. Sehingga berdasarkan SNI 15-1328-1989 dengan nilai tingkat mutu lulus uji sebesar $5.0 \%$ 
kelompok TY diterima. Sedangkan nilai rata-rata kuat tekan kelompok TY adalah $66.87 \mathrm{Kg} / \mathrm{cm}^{2}$. Maka kelompok TY memenuhi persyaratan SNI yaitu $>50 \mathrm{~kg} / \mathrm{cm}^{2}$.

Untuk pengujian kuat tekan kelompok TZ dari 10 buah sampel pengujian 3 buah sample yang memenuhi SNI 15-2094-2000 dan 7 buah sampel yang tidak memenuhi SNI 15-2094-2000. Sehingga berdasarkan SNI 15-1328-1989 dengan nilai tingkat mutu lulus uji sebesar $5.0 \%$ kelompok TY ditolak. Sedangkan nilai rata-rata kuat tekan kelompok TY adalah $39.84 \mathrm{Kg} / \mathrm{cm}^{2}$. Maka kelompok TY tidak memenuhi persyaratan SNI yaitu $<50 \mathrm{~kg} / \mathrm{cm}^{2}$.

Pengujian kuat tekan kelompok SX dari 10 buah sampel pengujian 5 buah sampel yang memenuhi SNI 15-2094-2000 dan 5 buah sampel tidak memenuhi SNI 15-2094 -2000. Sehingga berdasarkan SNI 15-1328-1989 dengan nilai tingkat mutu lulus uji sebesar 5.0 \% kelompok SX diterima. Sedangkan nilai rata-rata kuat tekan kelompok SX adalah $46.10 \mathrm{Kg} / \mathrm{cm}^{2}$. Maka kelompok SX tidak memenuhi persyaratan SNI yaitu $<50 \mathrm{~kg} / \mathrm{cm}^{2}$.

Untuk pengujian kuat tekan kelompok SY dari 10 buah sampel pengujian 9 buah sample yang memenuhi SNI 15-2094-2000 dan 1 buah sampel yang tidak memenuhi SNI 15-2094-2000. Sehingga berdasarkan SNI 15-1328-1989 dengan nilai tingkat mutu lulus uji sebesar 5.0 \% kelompok SY diterima. Sedangkan nilai rata-rata kuat tekan kelompok SY adalah $69.61 \mathrm{Kg} / \mathrm{cm}^{2}$. Maka kelompok SY memenuhi persyaratan SNI yaitu $>50 \mathrm{~kg} / \mathrm{cm}^{2}$.

Untuk pengujian kuat tekan kelompok SZ dari 10 buah sampel pengujian tidak ada yang memenuhi SNI 15-2094-2000. Sehingga berdasarkan SNI 15-1328-1989 dengan nilai tingkat mutu lulus uji sebesar $5.0 \%$ kelompok SZ ditolak. Sedangkan nilai rata-rata kuat tekan kelompok SZ adalah $23.48 \mathrm{Kg} / \mathrm{cm}^{2}$. Maka kelompok SZ tidak memenuhi persyaratan SNI yaitu $<50 \mathrm{~kg} / \mathrm{cm}^{2}$.

Pengujian kuat tekan kelompok UX dari 10 buah sampel pengujian 7 buah sampel yang memenuhi SNI 15-2094-2000 dan 3 buah sampel tidak memenuhi SNI 15-2094 -2000. Sehingga berdasarkan SNI 15-1328-1989 dengan nilai tingkat mutu lulus uji sebesar 5.0 \% kelompok UX diterima. Sedangkan nilai rata-rata kuat tekan kelompok UX adalah $57.51 \mathrm{Kg} / \mathrm{cm}^{2}$. Maka kelompok UX memenuhi persyaratan SNI yaitu $>50 \mathrm{~kg} / \mathrm{cm}^{2}$.

Untuk pengujian kuat tekan kelompok UY dari 10 buah sampel pengujian 3 buah sample yang memenuhi SNI 15-2094-2000 dan 7 buah sampel yang tidak memenuhi SNI 15-2094-2000. Sehingga berdasarkan SNI 15-1328-1989 dengan nilai tingkat mutu lulus uji sebesar 5.0 \% kelompok SY ditolak. Sedangkan nilai rata-rata kuat tekan kelompok UY adalah $42.74 \mathrm{Kg} / \mathrm{cm}^{2}$. Maka kelompok SY tidak memenuhi persyaratan SNI yaitu $<50 \mathrm{~kg} / \mathrm{cm}^{2}$.

Untuk pengujian kuat tekan kelompok UZ dari 10 buah sampel pengujian 7 buah sample yang memenuhi SNI 15-2094-2000 dan 3 buah sampel yang tidak memenuhi SNI 15-2094-2000. 
Sehingga berdasarkan SNI 15-1328-1989 dengan nilai tingkat mutu lulus uji sebesar 5.0 \% kelompok UZ diterima. Sedangkan nilai rata-rata kuat tekan kelompok UZ adalah $54.24 \mathrm{Kg} / \mathrm{cm}^{2}$. Maka kelompok UZ memenuhi persyaratan SNI yaitu $>50 \mathrm{~kg} / \mathrm{cm}^{2}$.

Pengujian kuat tekan kelompok PX dari 10 buah sampel pengujian 10 sampel tesrsebut memenuhi SNI 15-2094-2000. Sehingga berdasarkan SNI 15-1328-1989 dengan nilai tingkat mutu lulus uji sebesar $5.0 \%$ kelompok PX diterima. Sedangkan nilai rata-rata kuat tekan kelompok PX adalah $74.18 \mathrm{Kg} / \mathrm{cm}^{2}$. Maka kelompok PX memenuhi persyaratan SNI yaitu $>50 \mathrm{~kg} / \mathrm{cm}^{2}$.

Untuk pengujian kuat tekan kelompok PY dari 10 buah sampel pengujian 8 buah sample yang memenuhi SNI 15-2094-2000 dan 2 buah sampel yang tidak memenuhi SNI 15-2094-2000. Sehingga berdasarkan SNI 15-1328-1989 dengan nilai tingkat mutu lulus uji sebesar $5.0 \%$ kelompok PY diterima. Sedangkan nilai rata-rata kuat tekan kelompok PY adalah $61.96 \mathrm{Kg} / \mathrm{cm}^{2}$. Maka kelompok PY memenuhi persyaratan SNI yaitu $>50 \mathrm{~kg} / \mathrm{cm}^{2}$.

Untuk pengujian kuat tekan kelompok PZ dari 10 buah sampel pengujian 6 buah sample yang memenuhi SNI 15-2094-2000 dan 4 buah sampel yang tidak memenuhi SNI 15-2094-2000. Sehingga berdasarkan SNI 15-1328-1989 dengan nilai tingkat mutu lulus uji sebesar $5.0 \%$ kelompok PZ diterima. Sedangkan nilai rata-rata kuat tekan kelompok PZ adalah $50.98 \mathrm{Kg} / \mathrm{cm}^{2}$. Maka kelompok PZ memenuhi persyaratan SNI yaitu $>50 \mathrm{~kg} / \mathrm{cm}^{2}$.

Pengujian kuat tekan kelompok BX dari 10 buah sampel pengujian 4 buah sampel yang memenuhi SNI 15-2094-2000 dan 6 buah sampel tidak memenuhi SNI 15-2094 -2000. Sehingga berdasarkan SNI 15-1328-1989 dengan nilai tingkat mutu lulus uji sebesar 5.0 \% kelompok BX ditolak. Sedangkan nilai rata-rata kuat tekan kelompok BX adalah $48.81 \mathrm{Kg} / \mathrm{cm}^{2}$. Maka kelompok BX memenuhi persyaratan SNI yaitu $<50 \mathrm{~kg} / \mathrm{cm}^{2}$.

Untuk pengujian kuat tekan kelompok BY dari 10 buah sampel pengujian 7 buah sample yang memenuhi SNI 15-2094-2000 dan 3 buah sampel yang tidak memenuhi SNI 15-2094-2000. Sehingga berdasarkan SNI 15-1328-1989 dengan nilai tingkat mutu lulus uji sebesar $5.0 \%$ kelompok BY diterima. Sedangkan nilai rata-rata kuat tekan kelompok BY adalah $54.82 \mathrm{Kg} / \mathrm{cm}^{2}$. Maka kelompok SY tidak memenuhi persyaratan SNI yaitu $>50 \mathrm{~kg} / \mathrm{cm}^{2}$.

Untuk pengujian kuat tekan kelompok BZ dari 10 buah sampel pengujian 10 sampel tesrsebut memenuhi SNI 15-2094-2000. Sehingga berdasarkan SNI 15-1328-1989 dengan nilai tingkat mutu lulus uji sebesar $5.0 \%$ kelompok PX diterima. Sedangkan nilai rata-rata kuat tekan 
kelompok PX adalah $64.17 \mathrm{Kg} / \mathrm{cm}^{2}$. Maka kelompok PX memenuhi persyaratan SNI yaitu $>50 \mathrm{~kg} / \mathrm{cm}^{2}$.

Sedangkan pada hasil penelitian Temmy Ardian Darwin dengan judul "Pengaruh Bahan Tambah Serat Serabut Kelapa Terhadap Mutu Bata Merah Pejal Dengan SNI 15-2094-2000". Diperoleh hasil kuat tekan dari 10 sampel rata-rata $25.24 \mathrm{~kg} / \mathrm{cm}^{2}$.

\section{Penyerapan Air}

Pengujian penyerapan air kelompok TX dari 10 buah sampel pengujian 6 buah sampel yang memenuhi SNI 15-2094-2000 dan 4 buah sampel tidak memenuhi SNI 15-2094 -2000. Sehingga berdasarkan SNI 15-1328-1989 dengan nilai tingkat mutu lulus uji sebesar 5.0 \% kelompok TX diterima. Sedangkan nilai rata-rata penyerapan air kelompok TX adalah 19.94\%. Maka kelompok TX memenuhi persyaratan SNI yaitu $<20 \%$.

Untuk pengujian penyerapan air kelompok TY dari 10 buah sampel pengujian 6 buah sample yang memenuhi SNI 15-2094-2000 dan 4 buah sampel yang tidak memenuhi SNI 152094-2000. Sehingga berdasarkan SNI 15-1328-1989 dengan nilai tingkat mutu lulus uji sebesar $5.0 \%$ kelompok TY diterima. Sedangkan nilai rata-rata penyerapan air kelompok TY adalah 18.34 \%. Maka kelompok TY memenuhi persyaratan SNI yaitu < 20\%.

Untuk pengujian penyerapan air kelompok TZ dari 10 buah sampel pengujian 1 buah sample yang memenuhi SNI 15-2094-2000 dan 9 buah sampel yang tidak memenuhi SNI 152094-2000. Sehingga berdasarkan SNI 15-1328-1989 dengan nilai tingkat mutu lulus uji sebesar $5.0 \%$ kelompok TY ditolak. Sedangkan nilai rata-rata penyerapan air kelompok TY adalah 20.14\%. Maka kelompok TY tidak memenuhi persyaratan SNI yaitu $>20 \%$.

Pengujian penyerapan air kelompok SX dari 10 buah sampel pengujian 9 buah sampel yang memenuhi SNI 15-2094-2000 dan 1 buah sampel tidak memenuhi SNI 15-2094 -2000.

Sehingga berdasarkan SNI 15-1328-1989 dengan nilai tingkat mutu lulus uji sebesar 5.0 \% kelompok SX diterima. Sedangkan nilai rata-rata penyerapan air kelompok SX adalah $17.34 \%$. Maka kelompok SX memenuhi persyaratan SNI yaitu $<20 \%$.

Untuk pengujian penyerapan air kelompok SY dari 10 buah sampel pengujian 9 buah sample yang memenuhi SNI 15-2094-2000 dan 1 buah sampel yang tidak memenuhi SNI 152094-2000. Sehingga berdasarkan SNI 15-1328-1989 dengan nilai tingkat mutu lulus uji sebesar $5.0 \%$ kelompok SY diterima. Sedangkan nilai rata-rata penyerapan air kelompok SY adalah $17.34 \%$. Maka kelompok SY memenuhi persyaratan SNI yaitu $<20 \%$. 
Untuk pengujian penyerapan air kelompok SZ dari 10 buah sampel pengujian 9 buah sample yang memenuhi SNI 15-2094-2000 dan 1 buah sampel yang tidak memenuhi SNI 152094-2000. Sehingga berdasarkan SNI 15-1328-1989 dengan nilai tingkat mutu lulus uji sebesar $5.0 \%$ kelompok SZ diterima. Sedangkan nilai rata-rata penyerapan air kelompok SZ adalah 15.58\%. Maka kelompok SZ memenuhi persyaratan SNI yaitu $<20 \%$.

Pengujian penyerapan air kelompok UX dari 10 buah sampel pengujian 8 buah sampel yang memenuhi SNI 15-2094-2000 dan 2 buah sampel tidak memenuhi SNI 15-2094 -2000. Sehingga berdasarkan SNI 15-1328-1989 dengan nilai tingkat mutu lulus uji sebesar $5.0 \%$ kelompok UX diterima. Sedangkan nilai rata-rata penyerapan air kelompok UX adalah $17.59 \%$. Maka kelompok UX memenuhi persyaratan SNI yaitu $<20 \%$.

Untuk pengujian penyerapan air kelompok UY dari 10 buah sampel pengujian 9 buah sample yang memenuhi SNI 15-2094-2000 dan 1 buah sampel yang tidak memenuhi SNI 152094-2000. Sehingga berdasarkan SNI 15-1328-1989 dengan nilai tingkat mutu lulus uji sebesar $5.0 \%$ kelompok SY diterima. Sedangkan nilai rata-rata penyerapan air kelompok UY adalah 19.17\%. Maka kelompok SY tidak memenuhi persyaratan SNI yaitu $<20 \%$.

Untuk pengujian penyerapan air kelompok UZ dari 10 buah sampel pengujian 9 buah sample yang memenuhi SNI 15-2094-2000 dan 1 buah sampel yang tidak memenuhi SNI 152094-2000. Sehingga berdasarkan SNI 15-1328-1989 dengan nilai tingkat mutu lulus uji sebesar $5.0 \%$ kelompok UZ diterima. Sedangkan nilai rata-rata penyerapan air kelompok UZ adalah $17.58 \%$. Maka kelompok UZ memenuhi persyaratan SNI yaitu $<20 \%$.

Pengujian penyerapan air kelompok PX dari 10 buah sampel pengujian 10 sampel tesrsebut memenuhi SNI 15-2094-2000. Sehingga berdasarkan SNI 15-1328-1989 dengan nilai tingkat mutu lulus uji sebesar $5.0 \%$ kelompok PX diterima. Sedangkan nilai rata-rata penyerapan air kelompok PX adalah 17.84 \%. Maka kelompok PX memenuhi persyaratan SNI yaitu < $20 \%$.

Untuk pengujian penyerapan air kelompok PY dari 10 buah sampel pengujian 6 buah sample yang memenuhi SNI 15-2094-2000 dan 4 buah sampel yang tidak memenuhi SNI 152094-2000. Sehingga berdasarkan SNI 15-1328-1989 dengan nilai tingkat mutu lulus uji sebesar 5.0 \% kelompok PY diterima. Sedangkan nilai rata-rata penyerapan air kelompok PY adalah 19.5 \%. Maka kelompok PY memenuhi persyaratan SNI yaitu $<20 \%$.

Untuk pengujian penyerapan air kelompok PZ dari 10 buah sampel pengujian 7 buah sample yang memenuhi SNI 15-2094-2000 dan 3 buah sampel yang tidak memenuhi SNI 152094-2000. Sehingga berdasarkan SNI 15-1328-1989 dengan nilai tingkat mutu lulus uji sebesar 
$5.0 \%$ kelompok PZ diterima. Sedangkan nilai rata-rata penyerapan air kelompok PZ adalah 19.13 \%. Maka kelompok PZ memenuhi persyaratan SNI yaitu < $20 \%$.

Pengujian penyerapan air kelompok BX dari 10 buah sampel pengujian 10 sampel tersebut memenuhi SNI 15-2094-2000. Sehingga berdasarkan SNI 15-1328-1989 dengan nilai tingkat mutu lulus uji sebesar 5.0\% kelompok BX diterima. Sedangkan nilai rata-rata penyerapan air kelompok BX adalah $17.58 \%$. Maka kelompok BX memenuhi persyaratan SNI yaitu $<20 \%$.

Untuk pengujian penyerapan air kelompok BY dari 10 buah sampel pengujian 8 buah sample yang memenuhi SNI 15-2094-2000 dan 2 buah sampel yang tidak memenuhi SNI 152094-2000. Sehingga berdasarkan SNI 15-1328-1989 dengan nilai tingkat mutu lulus uji sebesar $5.0 \%$ kelompok BY diterima. Sedangkan nilai rata-rata penyerapan air kelompok BY adalah 17.63\%. Maka kelompok BY tidak memenuhi persyaratan SNI yaitu $<20 \%$.

Untuk pengujian penyerapan air kelompok BZ dari 10 buah sampel pengujian 9 buah sample yang memenuhi SNI 15-2094-2000 dan 1 buah sampel yang tidak memenuhi SNI 152094-2000. Sehingga berdasarkan SNI 15-1328-1989 dengan nilai tingkat mutu lulus uji sebesar $5.0 \%$ kelompok BZ diterima. Sedangkan nilai rata-rata penyerapan air kelompok BZ adalah $17.63 \%$. Maka kelompok BZ tidak memenuhi persyaratan SNI yaitu $<20 \%$.

Sedangkan pada hasil penelitian Temmy Ardian Darwin dengan judul "Pengaruh Bahan Tambah Serat Serabut Kelapa Terhadap Mutu Bata Merah Pejal Dengan SNI 15-2094-2000". Diperoleh hasil penyerapan air dari 10 sampel rata-rata $18.37 \%$.

\section{Kerapatan Semu}

Dalam SNI 15-2094-2000 nilai kerapatan semu bata merah pejal minimal adalah 1,2 gr/cm². Seluruh sampel benda uji dari tiap-tiap kelompok memenuhi SNI 15-2094-2000. Karena nilai kerapatan semu dari hasil penelitian rata-rata lebih dari $1,2 \mathrm{gr} / \mathrm{cm}^{2}$. Sehingga berdasarkan SNI 15-1328-1989 dengan nilai tingkat mutu lulus uji sebesar $5.0 \%$ seluruh sampel di tiap-tiap kelompok diterima. Nilai rata-rata Kerapatan Semu pada setiap kelompok disajikan dalam bentuk histogram dalam Gambar berikut:

Sedangkan pada hasil penelitian Temmy Ardian Darwin dengan judul "Pengaruh Bahan Tambah Serat Serabut Kelapa Terhadap Mutu Bata Merah Pejal Dengan SNI 15-2094-2000". Diperoleh hasil kerapatan semu dari 10 sampel rata-rata $1.76 \%$

\section{Garam yang Berbahaya}

Sesuai dengan SII 0021-78 pengujian bata merah pejal untuk garam yang berbahaya harus kurang dari $50 \%$. Pengujian garam yang berbahaya pada tiap-tiap kelompok. Maka seluruh 
sampel dari tiap-tiap kelompok memenuhi SII 0021-78. Sehingga berdasarkan SII 0021-78 dengan nilai tingkat mutu lulus uji sebesar $5.0 \%$ seluruh sampel di tiap-tiap kelompok diterima.

Sedangkan pada hasil penelitian Temmy Ardian Darwin dengan judul "Pengaruh Bahan Tambah Serat Serabut Kelapa Terhadap Mutu Bata Merah Pejal Dengan SNI 15-2094-2000". Diperoleh hasil garam yang ber bahaya dari 10 sampel rata-rata tidak mengandung garam yang berbahaya.

Berdasarkan tabel SNI 15-1328-1989 tentang syarat penerimaan mutu bata merah pejal. Diperoleh nilai tingkat mutu lulus uji sebesar 5.0\%. Maka dari hasil penelitian diatas dapat disimpulkan dgn tabel berikut :

Tabel 6 Tabel Rangkuman Hasil Pengujian Tiap-Tiap Kelompok

\begin{tabular}{|c|c|c|c|c|c|c|}
\hline $\begin{array}{l}\text { Pengujian } \\
\text { Kelompok }\end{array}$ & $\begin{array}{c}\text { Sifat } \\
\text { tampak }\end{array}$ & $\begin{array}{c}\text { Ukuran } \\
\text { dan } \\
\text { Toleransi }\end{array}$ & $\begin{array}{l}\text { Kuat } \\
\text { Tekan }\end{array}$ & $\begin{array}{l}\text { Kerapatan } \\
\text { Semu }\end{array}$ & $\begin{array}{c}\text { Penyerapan } \\
\text { Air }\end{array}$ & $\begin{array}{c}\text { Garam } \\
\text { yang } \\
\text { berbahaya }\end{array}$ \\
\hline$T X$ & $D$ & $T$ & $T$ & $D$ & $D$ & $D$ \\
\hline TY & $D$ & $\mathrm{~T}$ & $D$ & $D$ & $D$ & $D$ \\
\hline $\mathrm{TZ}$ & $D$ & $T$ & $T$ & $D$ & $T$ & $D$ \\
\hline$S X$ & $D$ & $T$ & $T$ & $D$ & $D$ & $D$ \\
\hline SY & $D$ & $\mathrm{~T}$ & $D$ & $D$ & $D$ & $D$ \\
\hline$S Z$ & $D$ & $\mathrm{~T}$ & $\mathrm{~T}$ & $D$ & $D$ & $D$ \\
\hline $\mathrm{BX}$ & $D$ & $T$ & $\mathrm{~T}$ & $D$ & $D$ & $D$ \\
\hline BY & $D$ & $T$ & $D$ & $D$ & $D$ & $D$ \\
\hline BZ & $D$ & $\mathrm{~T}$ & D & $D$ & D & D \\
\hline UX & $D$ & $T$ & $D$ & $D$ & $D$ & $D$ \\
\hline UY & $D$ & $T$ & $T$ & $D$ & $D$ & $D$ \\
\hline UZ & $D$ & $T$ & $D$ & $D$ & $D$ & $D$ \\
\hline $\mathrm{PX}$ & $D$ & $\mathrm{~T}$ & $D$ & $D$ & $D$ & $D$ \\
\hline PY & $D$ & $T$ & $D$ & $D$ & $D$ & $D$ \\
\hline $\mathrm{PZ}$ & $D$ & $\mathrm{~T}$ & $D$ & $D$ & $D$ & $D$ \\
\hline
\end{tabular}

Keterangan :

$\mathrm{D}$ = Diterima (Lulus Uji)

$\mathrm{T}=$ Ditolak (Tidak Lulus Uji)

\section{KESIMPULAN}

1. Berdasarkan SNI 15-2094-2000, syarat mutu bata merah pejal tradisional untuk sifat tampak adalah bidang permukaan bata merah pejal harus rata permukaan, rusuk-rusuknya siku dan tidak menimbulkan retak-retak. Hasil analisis dari ketiga pengujian sifat tampak 
tersebut menunjukkan sampel bata merah pejal tradisional di tiap-tiap wilayah memenuhi SNI 15-2094-2000.

2. Berdasarkan tabel ukuran SNI 15-2094-2000 hasil analisa ukuran dan toleransi, maka sampel bata merah pejal tradisional di tiap-tiap wilayah tidak memenuhi SNI 15-2094-2000.

3. Dalam SNI 15-2094-2000 nilai kuat tekan rata-rata minimum bata merah pejal adalah 50 $\mathrm{kg} / \mathrm{cm}^{2}$. Hasil analisa untuk kuat tekan rata-rata wilayah TX, TZ, SX, SZ, BX dan UY tidak memenuhi tingkat mutu bata merah pejal yang ada di SNI 15-2094-2000 karena hasil kuat tekan rata-rata $<50 \mathrm{~kg} / \mathrm{cm}^{2}$. Sedangkan nilai kuat tekan wilayah TY, SY, BY, BZ, UX,UZ, PX, PY dan PZ memenuhi tingkat mutu bata merah pejal yang ada di SNI 15-2094-2000 karena hasil kuat tekan rata-rata $>50 \mathrm{~kg} / \mathrm{cm}^{2}$.

4. Berdasarkan ketentuan dari SNI 15-2094-2000, nilai penyerapan air $<20 \%$ hasil analisa penyerapan air untuk wilayah TX-TY, SX-SY-SZ, BX-BY-BZ, UX-UY-UZ dan PX-PY-PZ lulus uji SNI 15-2094-2000. Karena nilai penyerapan air dari kelompok tersebut kurang dari 20\%. Sedangkan wilayah TZ tidak memenuhi mutu bata merah pejal yang ada di SNI 152094-2000 karena melebihi batas ketentuan SNI yaitu 20,14\%.

5. Dalam SNI 15-2094-2000 nilai kerapatan semu rata-rata minimum bata merah pejal adalah $1,2 \mathrm{gr} / \mathrm{cm}^{2}$. Hasil analisa untuk kerapatan semu adalah semua wilayah dari bata merah pejal memenuhi mutu SNI 15-2094-2000. Karena nilai kerapatan semu dari seluruh kelompok melebihi nilai ukuran yang ada di SNI 15-2094-2000.

6. Berdasarkan ketentuan dari SII 0021 - 78, nilai kandungan garam yang berbahaya pada bata merah pejal adalah kurang dari 50\%. Hasil analisa kandungan garam yang berbahaya di tiap-tiap wilayah memenuhi SII 0021 - 78, karena nilai kandungan garam kurang dari 50\%.++

\section{DAFTAR PUSTAKA}

Chandola, Varizani, V.N. Consise Handbook of Civil Engineering.

Daryanto. 1988. Pengetahuan Teknik Bangunan. Jakarta Bina Aksara.

Larasati. Penny. Pengujian Kuat Tarik Bata Merah Pejal. Jakarta : UNJ 2004

Rahardjo, Pentadri. 1996. Komponen Penentu Mutu Bata Merah Pejal di Pasaran Kodya Semarang dan Alternatif Upaya Peningkatannya. Semarang : Politeknik Universitas Diponegoro

SII 0021-1978. 1978. Pengujian Mutu Bata Merah Pejal. Jakarta : Departemen Perindustrian. 
SNI 15-1328-1989. 1989. Syarat Penerimaan Bata Merah Pejal. Jakarta : Badan Standarisasi Nasional.

SNI 15-2094-2000. 2000. Bata Merah Pejal Untuk Pasangan Dinding. Jakarta : Badan standarisasi nasional.

Sudjana. 1996. Metoda Statika. Bandung Tarsito.

Supribadi. IK. 1986. IImu Bangunan Gedung Seri Bangunan Sipil A. Bandung. Armico.

http://ms.wikipedia.org/wiki/jakarta.htm

http://toegas.blogspot.com/2009/02/contentmicrosoft-word-10-normal-0.html 